\title{
Observations on surface ornamentation in fossil Ostracoda
}

\author{
B. FITZ-GERALD \\ Postgraduate Unit of Micropalaeontology, Geology Department, \\ University College London, Gower Street, London WC1E 6BT
}

\begin{abstract}
It has recently been demonstrated (Okada, 1982) that some reticulate Ostracoda develop ornamentation by a process which reflects the arrangement of underlying epidermal cells. Pitting and secondary reticulation are also characteristic of many such forms, either during ontogeny or phylogeny, and as these features are of lesser dimensions than epidermal cells, a process at variance with that described by Okada must be responsible for their production. Outlined below is evidence from fossil Ostracoda supporting the hypothesis that actual valve resorption may occur during ontogeny to produce these second order features.
\end{abstract}

\section{INTRODUCTION}

Much recent work has been devoted to attempting to understand the function, variability and origin of ostracod surface ornament. In the past decade the 'Bensonian' view of ornament function, postulated by Benson (1974, 1975, $1981 \&$ 1982) and also Liebau (1977), has dominated the field although recent findings by Whatley, Trier \& Dingwall (1982) question the degree to which ornamentation confers mechanical strength. Indeed, the key to understanding the functional aspects of ornament may well emerge from a consideration of less elaborate needs such as intra-specific recognition. Keen (1982) discusses intra-specific variation, summarising previous work and concluding that environmental and genetic factors (polymorphism) contribute to the overall production of ornamental variation. Work concerning valve ultrastructure has proliferated in the past few years, with notable contributions from Bate \& East $(1972,1975)$ and latterly Rosenfeld (1982) and Dépêche (1982). Of particular relevance to the present paper is the work of Okada $(1981,1982 a, b)$ on the production of reticulate ornamentation in Recent cytheraceans. Employing transmission electron microscopy (TEM), Okada has succeeded in describing the development of ornamentation in Bicornucythere bisanensis (Okubo) and also notes a similar process in two species of Loxoconcha. Whilst agreeing with his findings, I feel that not all ornamental features fit into the class of ornament that arises as a result of the processes Okada describes. I have therefore set out to describe a number of these features below, and propose an additional process responsible for the production of surface ornament.

\section{OBSERVATIONS AND DISCUSSION}

Specimens of Hermanites hadropleura Hazel were recovered from a sample taken from the Coal Bluff Marl
Member of the Upper Palaeocene of Alabama (U.S.A.), together with specimens of $H$. bassleri (Ulrich). $H$. hadropleura is characteristic of the genus, with a reticulate surface ornament, well developed sub-central tubercle and prominent anteromarginal, dorsal, ventral and transverse ridges. Both adults and instars (mostly A-1) were found in reasonable numbers. When examined under the scanning electron microscope (SEM), the instars were found to exhibit a good deal of variation from individual to individual and an almost complete spectrum of morphotypes for the A-1 stage was eventually found (Pl. 1, figs. 1-9). The fine preservational state of many of the valves revealed a surface microornamentation of pits, arranged in a close-packed hexagonal pattern, covering the entire valve surface with the exception of muscle scar areas and fossae in adults. This type of micro-ornament has been found in four species of Hermanites, one other contemporary with $H$. hadropleura, and two from the mid Palaeocene of Alabama, and it compares structurally with Dépêche's microreticulation (Dépêche, 1982, Pl. 4, fig. 3).

The valves illustrated in Pl. 1, figs. $1-9$ are all A-1 instars and exhibit an ornamental variation from smooth ('celate' of Benson \& Sylvester-Bradley, 1971, Pl. 1, fig. 1) to fully reticulate (Pl. 1, fig. 9). It will be noted that the 'smooth' end members of this spectrum (Pl. 1, figs. 1-3) are not completely smooth but bear a system of vague surface ridges. These ridges demarcate areas (referred to here as 'proto-fossae areas') corresponding in position to the more prominent fossae in the fully reticulate morphs, as well as a variable number of small fossae usually developed in a cluster immediately anterior to the sub-central tubercle. In addition to this, closer examination reveals that the proto-fossae areas bear the surface micro-ornamentation mentioned above, in contrast to the sides and floors of fossae in the reticulate morphs which lack this micro-ornamentation. 
Referring to the sequence illustrated in Pl. 1, figs. 1-9, it is possible to note the way in which ornament is added in a sequence from smooth to reticulate. The first trace of ornamental development is the production of small depressions (or, more importantly, groups of depressions) within a proto-fossae area (Pl. 1, figs. 1-4, 10-12) within which the honeycomb of the microornamentation is eroded or absent. Tracing the development of these pits through the suite of morphotypes, it will be noted that they enlarge and coalesce (if formed in groups) and eventually 'excavate' a single fossa out of an originally smooth surface. This 'excavation' of the surface occurs in a definite sequence, with fossae being produced as follows:-

1. Anterior and anterodorsally to the sub-central tubercle.

2. Dorsal to the ventral longitudinal ridge, immediately posterior to the sub-central tubercle and ventral to the dorsal longitudinal ridge. The prominent line of fossae posterior to the anterior marginal rim is obscurely developed but becomes well established at Stage 3.

3. Row of anteromarginal fossae will developed-fossae begin to develop in the area bounded dorsally and ventrally by the median ridges, anteriorly by the subcentral tubercle and posteriorly by the transverse ridge

4. Finally, a single row of fossae immediately posterior and parallel to the anteromarginal fossae, and the triangular 'tail' posterior to the transverse ridge.

It is important to realise that $\mathrm{Pl}$. 1, figs. 1-9 represent stages through which any single valve passes before normal ornamentation is acquired. Thus, the valve is smooth immediately after ecdysis (fig. 1), becomes more ornate as the excavational processes proceed (figs. 2-8) and eventually develops normal reticulation (fig. 9), whereupon the excavation of the valve surface ceases. The evidence indicates (see below) that excavation occurs prior to and is halted by the onset of calcification. The variable timing of the beginning of calcification in different individuals may well account for the range of ornamental expression seen
Specimens of $H$. bassleri were found with $H$. hadropleura in the same sample. Although they appear exceedingly similar, and are undoubtedly closely related, the former species does not display the same degree of ornamental variation as the latter and at the present only one valve has been found which displays smooth areas of any great extent. It is reasonable to assume, however, that its ornament develops in exactly the same way as outlined above for $H$. hadropleura but that 'abnormal' valves of $H$. bassleri are rare. Among the many A-1 instars found, the posteriormost fossa (referred to as fossa ' $X$ ') exhibits a good deal of variation in its expression. In a few specimens it was absent (Pl. 2, fig. 3 ), its site being covered with the continuous 'honeycomb' micro-ornamentation characteristic of the unornamented surface of $H$. hadropleura, but vaguely indicated by the presence of granules $(0.5-0.7 \mu \mathrm{m}$ diam.) superimposed upon this surface. The next stage found in some individuals ( $\mathrm{Pl}$. 2, figs. 4, 6) has fossa ' $\mathrm{X}$ ' developed as a shallow, continuous elongate pit with a surface area equal to that of the fully developed fossa. Micro-ornamentation is still evident on the floor of the pit, whilst the granules, formerly arranged randomly, now tend to appear around the periphery of the pit giving the appearance of a string of beads. The most extreme development of this fossa in the A-1 instar is a moderately deep depression with micro-ornamentation absent from its floor; granules are still present. In adult specimens this fossa fuses with another located just anterior to it, the 'line of suture' sometimes indicated by a single row of granules.

The precise nature of the 'granules' found in $H$. bassleri (and also $H$. hadropleura) is at present unknown, but their association with proto-fossae areas (as above) and with fossae (in the 'string of beads' configuration) indicates that they may be a result of ornament-forming processes. Their occurrence is not restricted to the species of Hermanites discussed above, and the 'serrated edge' of fossae often found on close examination of reticulate forms may represent the eroded remnants of a former peripheral rim of granules (PI. 1, fig. 14).

\section{Explanation of Plate 1 \\ Hermanites hadropleura Hazel}

Figs. 1-9. Instars exhibiting variation in the degree of ornamentation. (Bar $=100 \mu \mathrm{m})$.

Figs. $10-12$. Excavation of proto-fossae. $(\operatorname{Bar}=10 \mu \mathrm{m})$.

Figs. 13,14 . 'String of beads' effect produced by peripheral granules. $(\mathrm{Bar}=10 \mu \mathrm{m})$.

Fig. 15. Detail of honeycomb micro-ornamentation. Note traces of central inclusion. $($ Bar $=1 \mu \mathrm{m})$. 

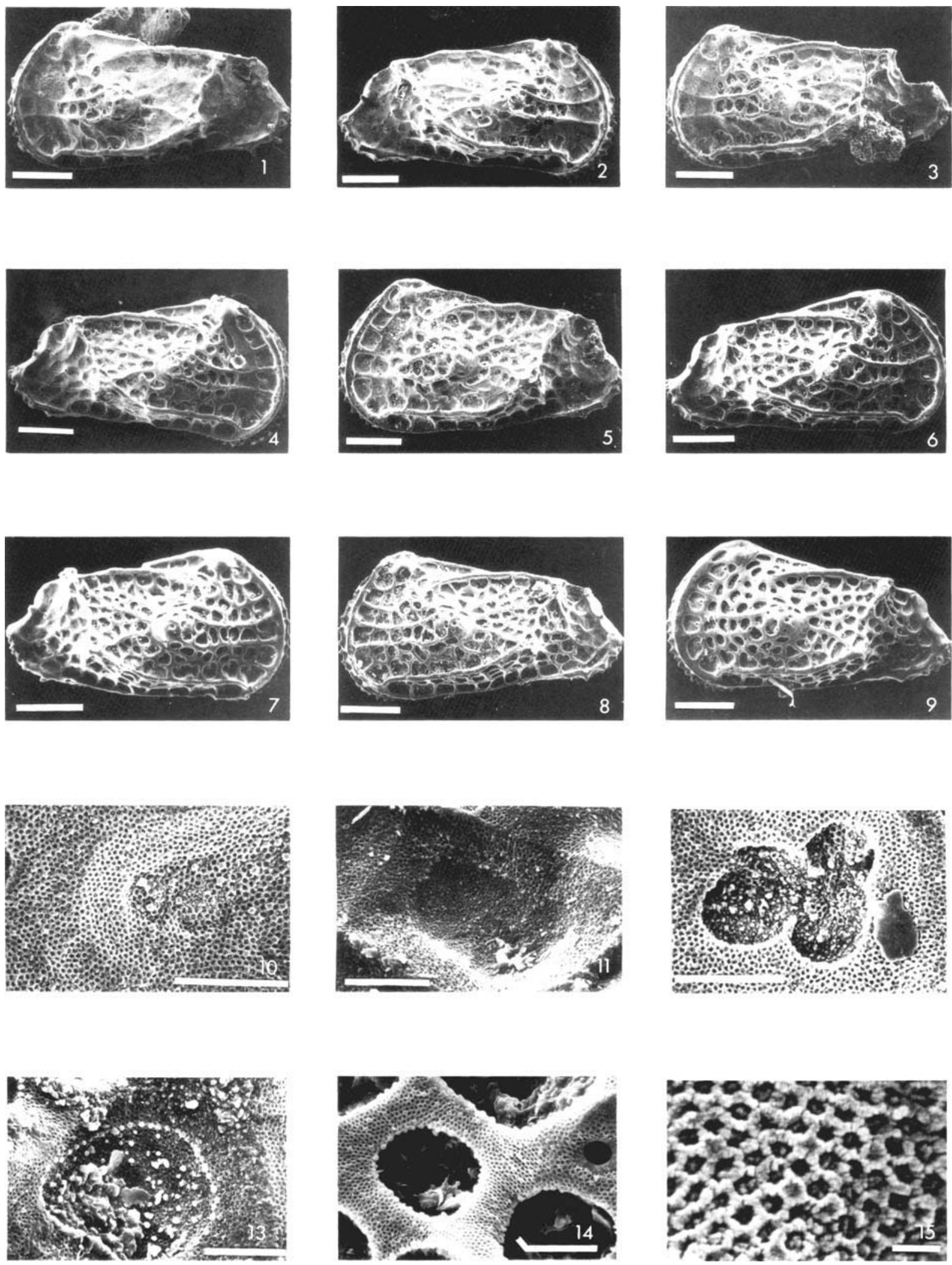
Further evidence suggesting an ornament-producing mechanism, as noted above in Hermanites, comes from the forms bearing 'trefoil' ornamentation (Benson \& Sylvester-Bradley, 1971). 'Trefoil' ornament refers to the small sharp spikes which extend from the muri into the fossae in this type of ornament and is exemplified in the discussion below by the species Acanthocythereis sp. cf. A. washingtonensis Hazel, specimens of which were collected from the upper Middle Palaeocene of Alabama. In the instars of this species the ornament was unlike that of adults and consisted of pits arranged in groups of 2,3 or 4 covering the entire valve surface ( $\mathrm{Pl}$. 2 , fig. 8). Reduction of the walls separating the pits in such a group would lead to the production of a single fossa, whilst an incomplete version of the same process would leave the stumps of the former inter-pit walls projecting into the newly-formed fossa as the spikes characteristic of 'trefoil' ornament. Thus, the process to produce trefoil ornament would be:-

i) The formation of pits in groups.

ii) Partial reduction of the inter-pit walls to give one fossa plus wall remnants (= spikes).

This is clearly a process involving the removal of valve material (in this case the inter-pit wall) to produce ornamentation.

In a few individuals of $A$. sp. ct. $A$. washingtonensis, occasional fossae are sub-divided by a thin septum extending from the lower surfaces of two spikes onto the walls and floors of the fossa (this septum may be found whole, or as a vestigial frill on the floor of the fossum and attached to the underside of the spikes (Pl. 2, figs. 9-10). This division represents a late stage in the excavation process just prior to the complete coalescence of two pits. Fossae containing septa are most frequently encountered on the posteroventral and anterodorsal parts of the valves. A related feature is the 'boss' frequently found in the centres of fossae (particularly in the anteromarginal fossae) which are made up of four pits and which represents the point of contact of the four inter-pit walls (Pl. 2, fig. 11).
Second order spines, which are frequently encountered in Acanthocythereis, may be accounted for by supposing that once produced, the spikes undergo a displacement, so that their long axes eventually become perpendicular to the valve surface. At this point a spike ceases to be a feature of the fossae and becomes a second order spine. This relationship between spines and spikes (see Fig. 1) suggests that the pit excavation and spine production occurs whilst the valve is in a flexible state and capable of expansion and deformation, i.e. prior to calcification. From the discussion of trefoil ornament above it is obvious that, as far as ornamental type is concerned, it represents underdeveloped reticulation and not a preliminary stage of fossa overgrowth as suggested by Benson \& Sylvester-Bradley (1971). Granulation arranged in the 'string of beads' pattern, mentioned above in the discussion of $H$. bassleri, is found in this species of Acanthocythereis and serves to reinforce the hypothesis that they share a common mode of ornament production.

\section{CONCLUSIONS}

From the above discussion it is apparent that a good deal of surface ornament seen in cytheracean ostracods could have evolved through a process akin to 'excavation' of the valve surface. Intra-specific variation would thus be a result of differing degrees of excavation of cuticle reached prior to calcification (the corollary being that the timing of calcification relative to the onset of ecdysis dictates the degree (type) of ornament on the valve surface). Thus smooth morphotypes (i.e. 'celate' individuals or those bearing ghost reticulation), exemplified above by the early ornament stages of $H$. hadropleura (Pl. 1, figs. 1-3), are not smooth as a result of the loss of reticulation but rather the reverse, in that they never developed it. These smooth forms of $H$. hadropleura bear proto-fossae areas, giving a 'ghost reticulation', and these areas form the 'plan' into which subsequent excavation fits (excavation never occurs

\section{Explanation of Plate 2}

Figs. 1-5. Hermanites bassleri (Ulrich): fig. 1, A-1 instar. Note discrete fossa ' $X$ '. $(B a r=100 \mu \mathrm{m})$; fig. 2, Adult. Note fused fossa ' $X$ '. (Bar $=100 \mu \mathrm{m})$; figs. 3-5, Development of fossa ' $X$ '. $($ Bar $=10 \mu \mathrm{m})$.

Figs. 6-11. Acanthocythereis sp.cf. A. washingtonensis Hazel: fig. 6, Adult. Note trefoil ornament. $($ Bar $=100 \mu \mathrm{m})$; fig. 7, Instar. Note grouping of pits. (Bar $=100 \mu \mathrm{m}$ ); figs. $8-10$. Trefoil fossae showing obscure 'string of beads' granulation and inter-pit septum. Note-these spikes are offset from one another. $($ Bar $=10 \mu \mathrm{m})$

Fig. 11. 'Boss' remaining at geometric centre of a 4-pit fossa. (Bar $=10 \mu \mathrm{m})$. 

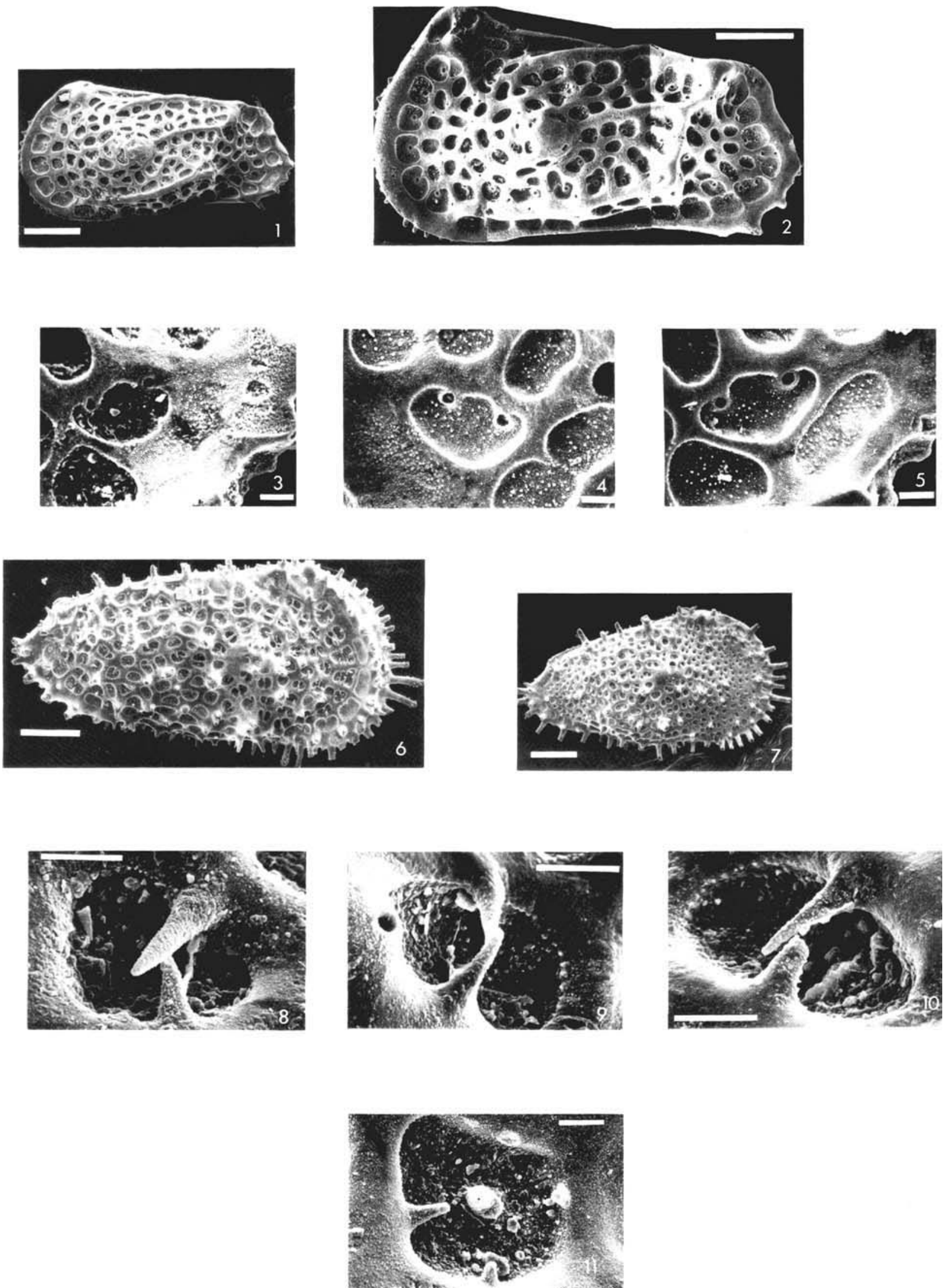
Fig. 1. Diagram illustrating the formation of trefoil ornament and second-order spines.
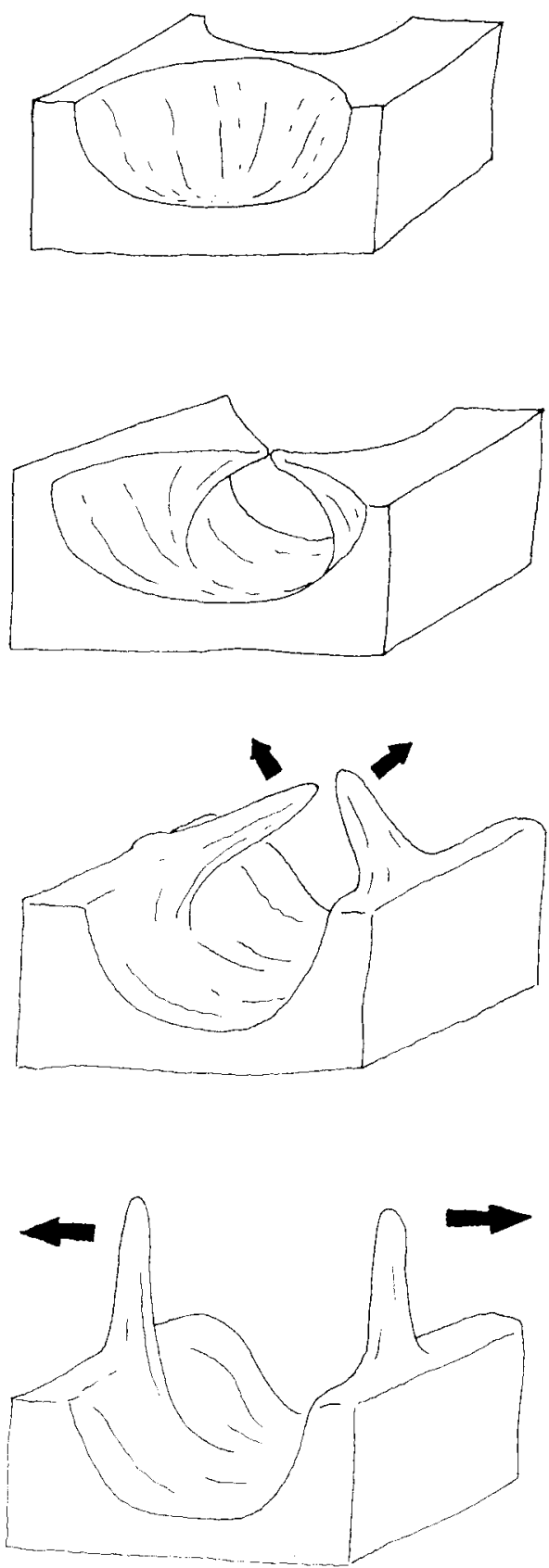

Displacement of spines due to valve expansion. across two such areas). These areas are fixed in any species, i.e. their positions are genetically encoded, and may well correspond in position to underlying epidermal cells (the positions of which are also encoded, see Okada, 1982). Liebau (1977) suggested that reticulate valves may loose their reticulation by a gradual replacement with microreticulation, usually associated with valve thinning, leading ultimately to the development of a smooth surface. The hypothesis of ornament by excavation allows these 3 stages to be linked in a developmental sequence, but in this case reversed, with the beginning of the sequence smooth and the end reticulate. Morphotype suites such as Cytheretta tenuipunctata (Bosquet) (see Keen, 1982) provide further examples of this type of ornamental development.

The processes of ornament production described by Okada (1982a, b) are probably responsible for the product of proto-fossae areas, with the expansion of his ' $T$ '-shaped junctions serving to delineate on the valve surface the impressions of the underlying epidermal cells. Beyond this point, in the species described above, the proto-fossae areas are modified by excavation (probably by enzymatic activity) to produce pits and later fossae, activities which are probably controlled by the underlying cell. If this is the case, the existence of dividing cells beneath a valve may explain the differential timing of ornament production over the valve area, a dividing cell being unable to undertake the production of pits and fossae as well as mitosis. Thus the areas developing late ornament in reticulate forms such as $H$. hadropleura may well indicate areas of cell division in the underlying epidermis.

\section{ACK NOWLEDGEMENTS}

I would like to thank Dr. A.R. Lord (University College London) and Dr. R.H. Bate (SSI (UK) Limited, Woking) for help and advice. Mr. M.M. Gay, Dr. A.J.J. Rees and Miss M. Norton (University College London) assisted with photography and manuscript preparation. A Natural Environment Research Council Research Studentship is gratefully acknowledged. Samples from the United States were collected with the aid of the Alabama Geological Survey. 


\section{REFERENCES}

Bate, R.H. \& East, B.A. 1972. The structure of the ostracod carapace. Lethaia, Oslo, 5, 177-194.

Bate, R.H. \& East, B.A. 1975. The ultrastructure of the ostracode (Crustacea) integument. Bull. Am. Paleont., Ithaca, 65, $529-547$.

Benson, R.H. 1974. The role of ornamentation in the design and function of the ostracod carapace. Geoscience and Man., Baton Rouge, 4, 47-57.

Benson, R.H. 1975. Morphological stability in Ostracoda. Bull. Am. Paleont., Ithaca, 65, 13-46.

Benson, R.H. 1981. Form, function and architecture of ostracode shells. Rev. Earth Planet Sci., 9, 59-80.

Benson, R.H. 1982. Comparative transformation of shape in a rapidly evolving series of structural morphotypes of the ostracoda Bradleya In Bate, R.H., Robinson, E. \& Sheppard, L.M. (Eds.), Fossil and Recent Ostracods, 145-164. Ellis Horwood Ltd., Chichester for British Micropalaeontological Society.

Benson, R.H. \& Sylvester-Bradley, P.C. 1971. Terminology for the surface features of ornate ostracoda. Lethaia, Oslo, 4, 249-286.

Dépêche, F. 1982. Ultrastructure of the wall in two living ostracods, Herpetocypris cheureusci (Sars) and Pontocythere elongata (Brady) in comparison with fossil ostracods from the Middle Jurassic of Normandy In Bate, R.H., Robinson, E. \& Sheppard, L.M. (Eds.), Fossil and Recent Ostracods, 61--74. Ellis Horwood Ltd., Chichester for British Micropalaeontological Society.
Hazel, J.E. 1968. Ostracods form the Brightseat Formation (Danian) of Maryland. J. Paleont., Tulsa, 42, 100-142.

Keen, M.C. 1982. Intraspecific variation in Tertiary ostracods In Bate, R.H., Robinson, E. \& Sheppard, L.M. (Eds.), Fossil and Recent Ostracods, 381-405. Ellis Horwood Ltd., Chichester for British Micropalaeontological Society.

Liebau, A. 1977. Carapace ornamentation of the Ostracode Cytheracea: principles of evolution and functional significance In Loffler, H. \& Danielopol, D. (Eds.), Aspects of Ecology and Zoogeography of Recent and Fossil Ostracoda, 107-120. Junk, The Hague.

Okada, Y. 1981. Development and cell arrangement in ostracod carapaces. Paleobiology, 7, 276-280.

Okada, Y. 1982a. Structure and cuticle formation of the reticulate carapace of the ostracode Bicornucythere bisanensis. Lethia, Oslo, 15, 85-101.

Okada, Y. 1982b. Ultrastructure and pattern of the carapace of Bicornucythere bisanensis (Ostracoda Crustacea) In Hanai, T. (Ed.), Studies on Japanese Ostracoda, University Museum of Tokyo Bulletin, 20, 229-267.

Rosenfeld, A. 1979. Structure and secretion of the carapace in some living Ostracodes. Lethia, Oslo, 12, 353-360.

Whatley, R.C., Trier, K. \& Dingwall, P.M. 1982. Some preliminary observations on certain mechanical and biophysical properties of the ostracod carapace In Bate, R.H., Robinson, E. \& Sheppard, L.M. (Eds.), Fossil and Recent Ostracods, 76-104. Ellis Horwood Ltd., Chichester for British Micropalaeontological Society. 